\title{
Comparative analysis of genetic diversity of 8 millet genera revealed by ISSR markers
}

\author{
Zdislava Dvořákováa, Petra Hlásná Čepkováa*, Dagmar Janovskáb, Iva Viehmannováa, Eva Svobodováa,1, \\ Eloy Fernández Cusimamania ${ }^{a}$ Luigi Milella ${ }^{c}$ \\ ${ }^{a}$ Czech University of Life Sciences Prague, Faculty of Tropical AgriSciences, Kamýcká 129, 16521 Prague 6, Suchdol, Czech Republic; ${ }^{1}$ Plant \\ Virus and Vector Interactions Team, Division of Crop Protection and Plant Health, Crop Research Institute, Drnovská 507, 16106 Prague \\ 6-Ruzyně, Czech Republic; 'Department of Gene Bank, Crop Research Institute, Drnovská 507, 16106 Prague 6-Ruzyně, Czech Republic \\ ${ }^{\circ}$ Department of Science, Università della Basilicata, 85100, Potenza, Italy
}

\section{A B S T R A C T}

The genetic diversity among different millet genera is not very well known; therefore, an investigation was undertaken with Inter Simple Sequence Repeats (ISSR) markers to ascertain the possibility of using these DNA markers to reveal the genetic relationships among different millet genera/species. Twelve out of 30 screened ISSR primers amplified successfully, and a total of 258 bands were scored for all 69 millet accessions, with a high level of polymorphism being detected. Nei's genetic distance among all accessions varied from 0.0241 to 0.3786 , and from 0.0163 to 0.1476 at the genera level, respectively. The Shannon's index was estimated as 0.9689 . The Neighbour joining (NJ) tree created, using the UnWeighted Neighbor-Joining method and Dice's dissimilarity coefficient, grouped all 69 millet accessions into eight clusters, indicating that the majority of accessions of a given genus tend to group together. The ISSR markers revealed the close relatedness between the Eragrostis and Panicum genera, as well as between Eragrostis and Pennisetum; while the greatest distance was found between the Coix and Setaria genera. Such a determination of relatedness is useful for a better understanding of the difficult relationships among the different millet genera, which are generally considered to be a complex group.

Keywords: Genetic distance; Genetic diversity; ISSR; Millet species; Polymorphism

\section{INTRODUCTION}

Millets represent a diverse group of cereal crops, comprising about a dozen crop species. They belong to different genera, which originated in Africa and Asia, were then subsequently domesticated, and are still cultivated there (McKevith, 2004; Baltensperger and Cai, 2004; FAO, 1995). Millets are small-grain cereals from the grass family (Poaceae) (Baltensperger and Cai, 2004). The millet group is split into two tribes. The tribe Paniceae comprises a number of different species such as Pennisetum glaucum (L.) R. Br., Setaria italica (L.) P. Beauv., Panicum miliaceum L., Coix lacryma-jobi L., Eragrostis tef (Zuccagni) Trotter, Echinochloa crus-galli (L.) P. Beauv., Digitaria exilis (Kippist) Stapf (Belton and Taylor, 2003). Finger millet (Eleusine coracana Gaertn.) is the only species of millet belonging to the second tribe, Chlorideae (Desai, 2004). A distinctive attribute of the millets are their adaptability to adverse agroecological conditions, minimal input requirements, and good nutritional properties. Millets represent a unique biodiversity component in agriculture, and play a significant role in food security for the developing countries in Asia and Africa. They also play a growing role in the processing, and new alternative products for the developed world (Obilana and Manyasa, 2002). From the nutritional point of view, millets are equivalent (or even superior to) other cereals (Lasztity, 1996; Obilana and Manyasa, 2002); moreover, they do not contain glutenforming proteins, making them important in a celiac diet (Amadou et al., 2013; Taylor et al., 2006). Compared to other cereals, millets are mainly suited to less fertile soils and poorer growing conditions, such as intense heat and low rainfall, where other cereal crops may likely fail (National Research Council, 1996; Winch, 2006). Beyond these indisputable qualities, many millet species have an important cultural significance, and play an irreplaceable role in social events and celebrations of the local people. Millets represent crucial plant genetic resources for the

*Corresponding author:

Suchdol, Czech Republic. Tel.:+420 224382 182, Fax: +420 234381 829, E-mail: cepkova@ftz.czu.cz

Received: 17 February 2015;

Revised: 26 April 2015;

Accepted: 04 May 2015;

Published Online: 04 May 2015 
agricultural and food security of poor farmers inhabiting arid, infertile, and marginal lands (Garí, 2002).

Traditionally, the genetic resources of the millet species were evaluated by: descriptions of their morphological characteristics (Andrews and Kumar, 2006; Brink and Belay, 2006; Kaume, 2006; Jansen and Ong, 1996; Jansen, 2006), by health-impact traits (Kalinová and Moudrý, 2006), and by molecular data. Current studies, based on DNA fingerprinting in millet species, have mainly been carried out for the identification of unknown accessions or genotypes within a single millet species (Supriya et al., 2011; Le Thierry d'Ennequin et al., 2000; Hu et al., 2009; Arya et al., 2013; Qin et al., 2005; Zeid et al., 2012, Nozawa et al., 2006; Adoukonou-Sagbadja et al., 2010).

Knowledge about the genetic diversity, and revelations of the genetic relationships among millet species is essential for the suitable conservation and increased use of millet genetic resources, and it also plays an important role in millet breeding. The application of methods using DNA analysis is pivotal for the description of genetic variability within different millet species. One of the alternatives is the use of Inter Simple Sequence Repeats (ISSR) markers, which is known to be a highly variable, reproducible, and cost effective method (Wolfe and Liston, 1998; Yang et al., 1996). Comparing ISSR markers with Random Amplified Polymorphic DNA (RAPD) analysis, there are many advantages on the side of ISSR, which can reveal a greater level of genetic variability. Using longer primers and higher annealing temperatures, they provide results that are more reliable and reproducible (Wolfe and Liston, 1998).

ISSR has been widely used in studies of the genetic structure of plants (Li and Jin, 2008), genetic diversity (Sheeja et al., 2009), genetic relationships (Li et al., 2009), phylogeny and evolution (Zamani et al., 2011). They have also been successfully applied to a number of monocotyledonous plants (Ben El Maati et al., 2004; Mondini et al., 2014; Bahieldin et al., 2012; Virk et al., 2000). Findings of genetic similarities in millet species have been performed using ISSR markers in Pennisetum, Setaria, Eleusine and Eragrostis genera (Pedraza-Garcia et al., 2010; Lin et al., 2012; Salimath et al., 1995; Assefa et al., 2003). On the other hand, ISSR markers have never been applied to studies focusing on the genetic diversity of the various other species of millet genera (such as Panicum, Echinochloa, Coix, and Digitaria).

There is a deficit of information about the levels of genetic variability among different millet species, and there is also no information available about the genetic relationships among the different genera. The motivation for this study was to uncover the linkages within the group of millet species by the use of ISSR markers.

\section{MATERIALS AND METHODS}

\section{Plant materials}

A set of 69 accessions, belonging to 8 millet genera, was used (Table 1). Selected millet samples were obtained from the Czech Gene Bank of the Crop Research Institute (CRI), Prague, Czech Republic; from the Botanical Garden of Faculty of Tropical AgriSciences, Czech University of Life Sciences Prague, Czech Republic; as well as from the United States Department of Agriculture (USDA), Iowa State University.

\section{DNA extraction, ISSR amplification, and scoring}

Young leaves were obtained from plants grown in the greenhouses at the Botanical Garden of Faculty of Tropical AgriSciences CULS Prague, Czech Republic. The fresh leaves were frozen using liquid nitrogen to be ground into a fine powder. Total genomic DNA was isolated using an Invisorb $^{\circledR}$ Spin Plant Mini Kit (Stratec Molecular, Berlin, Germany). The DNA concentration was determined using a Micro-spectrophotometer, UVS-99 (ACT Gene, Piscataway, NJ, USA). A portion of the DNA was diluted to $50 \mathrm{ng} / \mu \mathrm{l}$, for use in the ISSR analysis, and both the stock and diluted portions were stored at $-20^{\circ} \mathrm{C}$.

A set of 30 ISSR primers (University of British Columbia, Vancouver, Canada) were tested. A set of testing samples, which consisted of every millet species, was used to screen for suitable primers. Twelve reproducible ISSR primers were selected for the final analysis (Table 2).

Every $20 \mu \mathrm{l}$ of PCR reaction mixture was composed of: $10 \mu \mathrm{l}$ of $2 \mathrm{x}$ PPP Master Mix [150 mM Tris-HCl, $\mathrm{pH} 8.8\left(25^{\circ} \mathrm{C}\right), 40 \mathrm{mM}\left(\mathrm{NH}_{4}\right)_{2} \mathrm{SO}_{4}, 0.02 \%$ Tween, $20.5 \mathrm{mM}$ $\mathrm{MgCl}_{2}, 400 \mu \mathrm{M}$ dATP, $400 \mu \mathrm{M}$ dCTP, $400 \mu \mathrm{M}$ dGTP, $400 \mu \mathrm{M}$ dTTP, $100 \mathrm{U} / \mathrm{ml}$ Taq-Purple DNA polymerase, monoclonal antibody anti-Taq $(38 \mathrm{nM})$, stabilizers, and additives (Tob-Bio, Czech Republic)], $10 \mu \mathrm{M}$ of respective ISSR primer (Integrated DNA Technologies, Belgium), 2 $\mu \mathrm{l}$ of DNA ( $50 \mathrm{ng} / \mu \mathrm{l}), 0.2 \mu \mathrm{l}$ of BSA (Thermo Scientific, USA), and 7.3 $\mu$ PCR $\mathrm{H}_{2} \mathrm{O}$ (Top-Bio, Czech Republic). The ISSR analysis was carried out using a QB96 Server Gradient Thermal Cycler (Quanta Biotech, UK).

The PCR was carried out with modifications of the annealing temperature to optimize the reaction for individual primers. The cycling conditions were as follows: initial denaturation step at $95^{\circ} \mathrm{C}$ for $4 \mathrm{~min}$, followed by 45 cycles of denaturation at $94^{\circ} \mathrm{C}$ for $30 \mathrm{~s}$, primer annealing at $45-58^{\circ} \mathrm{C}$ for $45 \mathrm{~s}$ (Table 2), and extension at $72^{\circ} \mathrm{C}$ for $2 \mathrm{~min}$, followed by a final extension at $72^{\circ} \mathrm{C}$ for $10 \mathrm{~min}$. Amplified products were mixed with loading dye (Thermo Scientific, USA) and loaded onto the gel. Electrophoretic separation was performed on $2 \%$ agarose 
Table 1: Millet accessions

\begin{tabular}{|c|c|c|c|c|}
\hline & Name & Donor & Code of donor & Origin \\
\hline 1 & Pennisetum ciliare (L.) Link & USDA & PI 161631 & South Africa \\
\hline 2 & Pennisetum ciliare (L.) Link & USDA & PI 22966202 & Madagascar \\
\hline 3 & Pennisetum glaucum (L.) R. Br. & USDA & PI 288801 & India \\
\hline 4 & Pennisetum glaucum (L.) R. Br. & USDA & PI 337492 & Brazil \\
\hline 5 & Pennisetum glaucum (L.) R. Br. & USDA & PI 33135301 & Uganda \\
\hline 6 & Pennisetum glaucum (L.) R. Br. & USDA & PI 34384201 & Senegal \\
\hline 7 & Pennisetum glaucum (L.) R. Br. & USDA & PI 52741301 & Algeria \\
\hline 8 & Pennisetum glaucum (L.) R. Br. & USDA & PI 53217601 & Oman \\
\hline 9 & Pennisetum purpureum Schumach. & USDA & PI 31642102 & Mexico \\
\hline 10 & Pennisetum sieberianum (Schltdl.) Stapf \& C. E. Hubb. & USDA & PI 532675 & Mali \\
\hline 11 & Setaria italica L. subs. italica & USDA & PI 464525 & India \\
\hline 12 & Setaria italica L. subs. italica & USDA & PI 212626 & Afghanistan \\
\hline 13 & Setaria italica L. subs. italica & USDA & PI 433391 & Taiwan \\
\hline 14 & Setaria incrassata (Hochst.) Hack. & USDA & PI 209210 & South Africa \\
\hline 15 & Setaria pumila (Poir.) Roem. \& Schult. & USDA & PI 206460 & Turkey \\
\hline 16 & Panicum bergii Arechav. & USDA & PI 31003101 & Brazil \\
\hline 17 & Panicum coloratum L. & USDA & PI 22499101 & South Africa \\
\hline 18 & Panicum coloratum $\mathrm{L}$. & USDA & PI 22558001 & South Africa \\
\hline 19 & Panicum coloratum L. & USDA & PI 22558201 & Zambia \\
\hline 20 & Panicum coloratum L. var. coloratum & USDA & PI 22608501 & Kenya \\
\hline 21 & Panicum deustum Thunb. & USDA & PI 36495501 & South Africa \\
\hline 22 & Panicum dregeanum Nees & USDA & PI 36495601 & South Africa \\
\hline 23 & Panicum lanipes $\mathrm{Mez}$ & USDA & PI 23834601 & Zaire \\
\hline 24 & Panicum miliaceum L. & CULS & & not known \\
\hline 25 & Panicum miliaceum $\mathrm{L}$. & CULS & & not known \\
\hline 26 & Panicum schinzii Hack. & USDA & PI 28415301 & Cyprus \\
\hline 27 & Panicum sumatrense Roth & USDA & Ames 14464 & India \\
\hline 28 & Panicum virgatum $\mathrm{L}$. & USDA & PI 42190101 & Florida, USA \\
\hline 29 & Eleusine coracana (L.) Gaertn. & USDA & PI 214059 & India \\
\hline 30 & Eleusine floccifolia (Forssk.) Spreng. & USDA & PI 196853 & Ethiopia \\
\hline 31 & Eleusine indica (L.) GAERTN. & CRI & $14 Z 2500001$ & Belgium \\
\hline 32 & Eleusine indica (L.) Gaertner. & USDA & PI 22627001 & Zimbabwe \\
\hline 33 & Eleusine multiflora Hochst. ex A. Rich. & USDA & PI 22606701 & Kenya \\
\hline 34 & Eleusine tristachya KUNTH. & CRI & $14 Z 2500002$ & Sweden \\
\hline 35 & Coix lacryma-jobi L. & USDA & PI 324509 & Japan \\
\hline 36 & Coix lacryma-jobi L. & USDA & PI 320865 & India \\
\hline 37 & Eragrostis bahiensis Schrad. ex Schult. & USDA & PI 203648 & Brazil \\
\hline 38 & Eragrostis capensis (Thunb.) Trin. & USDA & PI 364803 & Brazil \\
\hline 39 & Eragrostis cilianensis subs. starosselskyi (Grossh.) Tzvelev & USDA & PI 212297 & Afghanistan \\
\hline 40 & Eragrostis curvula (Schrad.) Nees & USDA & PI 156818 & South Africa \\
\hline 41 & Eragrostis cylindriflora Hochst. & USDA & PI 364817 & South Africa \\
\hline 42 & Eragrostis lappula Nees & USDA & PI 364260 & Brazil \\
\hline 43 & Eragrostis lugens Nees & USDA & PI 203862 & Brazil \\
\hline 44 & Eragrostis obtusa Munro ex Ficalho \& Hiern & USDA & PI 344546 & South Africa \\
\hline 45 & Eragrostis pilosa (L.) P. Beauv. & USDA & PI 223259 & Afghanistan \\
\hline 46 & Eragrostis plana Nees & USDA & PI 364340 & South Africa \\
\hline 47 & Eragrostis racemosa (Thunb.) Steud. & USDA & PI 192959 & Kenya \\
\hline 48 & Eragrostis rigidior Pilg. & USDA & PI 364824 & Afghanistan \\
\hline 49 & Eragrostis rotifer Rendle & USDA & PI 208131 & South Africa \\
\hline 50 & Eragrostis rotifer Rendle & USDA & PI 364825 & Afghanistan \\
\hline 51 & Eragrostis secundiflora subsp. oxylepis (Torr.) S. D. Koch & USDA & PI 295692 & South Africa \\
\hline 52 & Eragrostis superba Peyr. & USDA & PI 442111 & Japan \\
\hline 53 & Eragrostis tef (Zuccagni) Trotter & USDA & PI 494388 & Ethiopia \\
\hline 54 & Eragrostis tef (Zuccagni) Trotter & USDA & PI 442115 & Japan \\
\hline 55 & Echinochloa crus-galli (L.) BEAUV. & CRI & $01 Z 3010001$ & Czech Republic \\
\hline 56 & Echinochloa crus-galli (L.) BEAUV. & $\mathrm{CRI}$ & $01 Z 3010002$ & Czech Republic \\
\hline
\end{tabular}


Table 1: (Continued...)

\begin{tabular}{|c|c|c|c|c|}
\hline & Name & Donor & Code of donor & Origin \\
\hline 57 & Echinochloa esculenta (A. Braun) H. Scholz & USDA & PI 315699 & Florida, USA \\
\hline 58 & Echinochloa frumentacea LINK & CRI & $01 Z 3000001$ & not known \\
\hline 59 & Echinochloa frumentacea LINK & USDA & PI 463803 & India \\
\hline 60 & Echinochloa pyramidalis (Lam.) Hitchc. \& Chase & USDA & PI 207924 & South Africa \\
\hline 61 & Digitaria brownii (Roem. \& Schult.) Hughes & USDA & PI 23828601 & South Africa \\
\hline 62 & Digitaria debilis (Desf.) Willd. & USDA & PI 29959602 & Lesotho \\
\hline 63 & Digitaria eriantha Steud. & USDA & PI 29979401 & South Africa \\
\hline 64 & Digitaria exilis (Kippist) Stapf & USDA & PI 349688 & Nigeria \\
\hline 65 & Digitaria gazensis Rendle & USDA & PI 25843101 & South Africa \\
\hline 66 & Digitaria leptorrhachis (Pilg.) Stapf & USDA & PI 36451701 & South Africa \\
\hline 67 & Digitaria milanjiana (Rendle) Stapf & USDA & PI 40980401 & South Africa \\
\hline 68 & Digitaria sanguinalis (L.) SCOP. & CRI & $01 Z 2900002$ & Czech Republic \\
\hline 69 & Digitaria swazilandensis Stent & USDA & PI 23829001 & Zimbabwe \\
\hline
\end{tabular}

Table 2: Characterization of ISSR markers (Zietkiewicz et al., 1994) used in this study and their polymorphism

\begin{tabular}{|c|c|c|c|c|c|c|c|}
\hline No. & $\begin{array}{l}\text { Primers } \\
\text { code (UBC) }\end{array}$ & $\begin{array}{l}\text { Sequence } \\
5^{\prime}-3^{\prime}\end{array}$ & $\begin{array}{c}\text { Annealing } \\
\text { temperature }\left({ }^{\circ} \mathrm{C}\right)\end{array}$ & $\begin{array}{l}\text { Total number of } \\
\text { bands amplified }\end{array}$ & $\begin{array}{l}\text { Number of scorable } \\
\text { bands per primer }\end{array}$ & $\begin{array}{l}\text { No. and frequency of } \\
\text { polymorphic bands per primer }\end{array}$ & $\begin{array}{c}\text { Range of } \\
\text { amplification (bp) }\end{array}$ \\
\hline 1 & UBC810 & $(\mathrm{GA})_{8} \mathrm{~T}$ & 55 & 262 & 16 & $16(100 \%)$ & $250-2500$ \\
\hline 2 & UBC812 & $(\mathrm{GA})_{8} \mathrm{~A}$ & 52 & 175 & 16 & $16(100 \%)$ & $350-2500$ \\
\hline 3 & UBC824 & $(\mathrm{TC})_{8} \mathrm{G}$ & 55 & 329 & 25 & $25(100 \%)$ & $350-2500$ \\
\hline 4 & UBC834 & $(\mathrm{AG})_{8} \mathrm{YT}$ & 48 & 392 & 22 & $22(100 \%)$ & $350-2000$ \\
\hline 5 & UBC840 & $(\mathrm{GA})_{8} \mathrm{YT}$ & 52 & 437 & 24 & $24(100 \%)$ & $250-3000$ \\
\hline 6 & UBC841 & $(G A)_{8} Y C$ & 48 & 532 & 24 & $23(95.83 \%)$ & $250-2500$ \\
\hline 7 & UBC846 & $(\mathrm{CA})_{8} \mathrm{RT}$ & 48 & 361 & 21 & $21(100 \%)$ & $400-2500$ \\
\hline 8 & UBC848 & $(\mathrm{CA})_{8} \mathrm{RG}$ & 48 & 442 & 22 & $22(100 \%)$ & $350-2500$ \\
\hline 9 & UBC854 & $(\mathrm{TC})_{8} \mathrm{RG}$ & 52 & 425 & 22 & $22(100 \%)$ & $300-2500$ \\
\hline 10 & UBC855 & $(\mathrm{AC})_{8} \mathrm{YT}$ & 52 & 434 & 24 & $24(100 \%)$ & $300-2500$ \\
\hline 11 & UBC859 & $(\mathrm{TG})_{8} \mathrm{RC}$ & 50 & 326 & 21 & $21(100 \%)$ & $400-2000$ \\
\hline \multirow[t]{3}{*}{12} & UBC873 & $(\mathrm{GACA})_{4}$ & 52 & 314 & 21 & $21(100 \%)$ & $350-2500$ \\
\hline & & Total & - & 4429 & 258 & 257 (99.61\%) & - \\
\hline & & Mean & - & - & 21.5 & 21.42 & - \\
\hline
\end{tabular}

gel in $1 \mathrm{x}$ TBE buffer. Gels were run for about $2.5-3 \mathrm{~h}$ at 4 V.cm ${ }^{-1}$. Gels were stained with $\mathrm{SYBR}^{\circledR}$ Safe DNA Gel Stain (Life technologies, USA), and visualized with a UV transilluminator. The banding pattern was recorded using a CSL-MICRODOC System (CLEAVER, United Kingdom). PCR amplification of the samples with each primer was carried out in duplicate to ensure the consistency and reproducibility of the results.

\section{Data analysis}

ISSR fragments were scored for the presence (1) or absence (0) of bands in the gel profile. Only strong and clear bands were used to construct a binary matrix. The binary matrix was used to calculate a dissimilarity matrix using Dice's coefficient (Dice, 1945). Data were analyzed using DARwin 5 software (Perrier and Jacquemoud-Collet, 2006), and then a final Neighbour joining (NJ) dendrogram (Saitou and Nei, 1987) was constructed by means of the UnWeighted Neighbor-Joining method. Shannon's information index $(I, \operatorname{LogBase}=\mathrm{e})$ was estimated by fingerprinting analysis with missing data (FAMD) software, version 1.31 (Schlüter and Harris, 2006) for all accessions according to Hutchenson (1970) and normalised according to Ramezani (2012). The percentage of polymorphic bands and Nei's genetic distance (Nei, 1972; Nei and Takezaki, 1983) were calculated by using FAMD. The Principal Coordinates Analysis (PCoA) was performed by software DARwin 5.0 using the data obtained from the calculation of the Dice's coefficient.

\section{RESULTS}

\section{ISSR profile and analysis}

In this study, 12 ISSR (Table 2) were then used to analyze the genetic diversity of 69 millet accessions. These 12 primers A total of 258 fragments, ranging from 250 to $2500 \mathrm{bp}$, were amplified with a mean of 21.5 bands per primer, of which 257 (99.61\%) were polymorphic. Absolute polymorphism (100.0\%) was observed with primers UBC810, UBC812, UBC824, UBC834, UBC840, UBC846, UBC848 UBC854, UBC855, UBC859, and UBC873; while the lowest level of polymorphism (95.83\%) was observed 
with primer UBC841 (Table 2). The highest number of polymorphic bands was produced by UBC824 (25 polymorphic bands); while the lowest number was obtained from UBC810 and UBC812 (16 polymorphic bands).

The number of bands generated by the ISSR primers within a single genus varied from 31 to 230 . The level of polymorphism within a single genus varied from $12.06 \%$ in the Coix genus to $89.88 \%$ in the Eragrostis genus, with a mean of $65.81 \%$.

\section{Genetic diversity within and among genera}

Shannon's index among all 69 samples was estimated at 0.9689. The Nei's genetic distance matrix among all millet accessions was found to be in the range of 0.0241 to 0.3786 (mean of 0.1922 ). The maximum genetic distance was between Eragrostis tef (accession No. 53) and Panicum sumatrense (accession No. 27), while the lowest genetic distance was between Eragrostis cylindriflora (accession No. 41) and Eragrostis racemosa (accession No. 47).

At the genus level, the values of Nei's genetic distance indicated a high level of variation (Table 3 ). The greatest distance was found between the Coix and Setaria genera (0.1476), while the lowest genetic distance was between the Eragrostis and Panicum genera (0.0163).

\section{Cluster analyses based on the ISSR genotyping profile}

A dendrogram based on Neighbour joining analysis of the ISSR data was constructed in order to be able to infer the phylogenetic relationships among 69 millet accessions belonging to eight genera. The dendrogram showed that, in most cases, accessions of the same millet genus clustered together (Fig. 1).

According to the dendrogram, all 69 accessions were separated into eight clusters. Cluster I consists of 11 millet accessions belonging to four millet genera, viz. Eragrostis, Eleusine, Panicum, and Digitaria. The Eragrostis accessions formed a distinct branch consisting of four accessions; whereas, Eragrostis cylindriflora -No. 41 (South Africa origin) and Eragrostis racemosa -No. 47 (Kenyan origin) showed the highest similarity to all millet accessions. Three Digitaria accessions (Nos. 62, 67, and 68) also comprised a distinct branch. Similar to Cluster I, Cluster II was also mostly formed by Eragrostis accessions. Also present were accessions of other millet genera, viz. Eleusine, Pennisetum, Panicum, and Digitaria.

Cluster III primarily contained Pennisetum accessions, followed by Coix, Digitaria, and Eragrostis accessions. Pennisetum accessions of this cluster grouped together; another five Pennisetum accessions did not fall within the same group, but fell into a different cluster (Cluster 7); meaning that the intraspecific genetic diversity among those accessions was large. Although Coix accessions (Nos. 36 and 35) clustered with other millet genera, these two accessions formed a distinct branch. Both accessions originated in Asia, specifically in India and Japan.

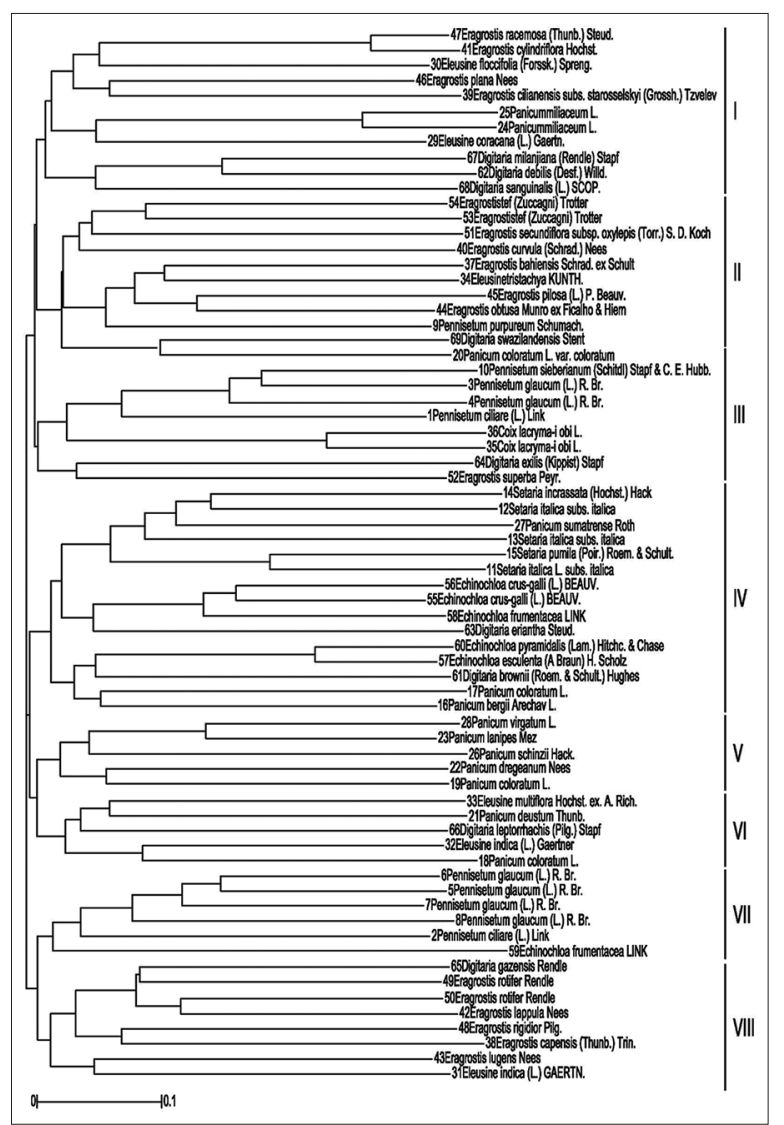

Fig 1. NJ dendrogram showing relationships among and wihtin different millet genera. Dendrogram constructed on the basis of ISSR markers.

Table 3: Genetic distance matrix among 8 millet genera

\begin{tabular}{lccccccc}
\hline & Pennisetum & Coix & Eleusine & Eragrostis & Digitaria & Echinochloa & Panicum \\
\hline Pennisetum & 0.0000 & & & & & & \\
Coix & 0.1185 & 0.0000 & & & & & \\
Eleusine & 0.0369 & 0.1259 & 0.0000 & & & & \\
Eragrostis & 0.0206 & 0.1229 & 0.0271 & 0.0000 & & & \\
Digitaria & 0.0305 & 0.1250 & 0.0266 & 0.0234 & 0.0000 & & \\
Echinochloa & 0.0385 & 0.1293 & 0.0451 & 0.0403 & 0.0423 & 0.0000 & 0.0000 \\
Panicum & 0.0229 & 0.1270 & 0.0295 & 0.0163 & 0.0257 & 0.0443 & 0.0648 \\
Setaria & 0.0625 & 0.1476 & 0.0685 & 0.0573 & 0.0586 & 0.0624 & 0.0000 \\
\hline
\end{tabular}


In Cluster IV, Setaria, Digitaria, Echinochloa, and Panicum accessions clustered together. The Setaria accessions formed a distinct branch consisting of five Setaria accessions (Nos.11, 12, 13, 14, and 15), with one accession of Panicum sumatrense - No. 27. The other two accessions of Panicum, viz. Panicum coloratum - No. 17 and Panicum bergii - No. 16 showed quite high dissimilarities.

Cluster V was composed entirely of Panicum accessions, viz. Panicum virgatum - No. 28, Panicum lanipes - No. 23, Panicum schinzii - No. 26, Panicum dregeanum - No. 22, and Panicum coloratum - No. 19. Other Panicum accessions appeared scattered in the dendrogram, possibly due to the large intraspecific genetic diversity among the Panicum accessions.

Cluster VI showed a high degree of admixtures of millet genera; the cluster was formed by Panicum, Eleusine, and Digitaria accessions. The accessions Panicum coloratum -No. 18 and Eleusine indica - No. 32 were quite similar.

Cluster VII was formed almost completely by accessions of one millet genus, specifically by the Pennisetum genus. Four of these five Pennisetum accessions belong to the same species - Pennisetum glaucum, specifically Nos. 5, 6, 7, and 8. The fifth Pennisetum accession of that cluster was accession No. 2 - Pennisetum ciliare. From these five accessions, two accessions of Pennisetum glaucum were the most similar, specifically, Nos. 6 and 5.

Cluster VIII primarily included Eragrostis accessions and one accession of Digitaria and Eleusine, Nos. 65 and 31, respectively. Digitaria gazensis - No. 65 showed a high similarity with Eragrostis rotifer - No. 49. The most similar were Eragrostis rotifer - No. 50 and Eragrostis lappula - No. 42.

PCoA was performed to further explore the relationships among millets with ISSR data. Millet accessions were scattered on the graphic area of PCoA diagram with no evident clusters. Only Setaria and Echinochloa accessions were quite well separated from another millet accessions, which corresponds with the dendrogram.

\section{DISCUSSION}

Despite the importance of millets, the available information of both their phylogenetic relationships and genetic diversity, using molecular markers, is still rather limited. In most of the studies, which were focused on genetic diversity and the relationships of millets, only one millet species or genus (Li et al., 2012; Assefa et al., 2003; Yu et al., 2006; Salimath et al., 1995, Arya et al., 2013, Kim et al., 2014) was often involved; whereas, the current study was aimed at revealing the relationship among and within different millet genera, simultaneously.
In the present study, a Neighbour joining dendrogram offers a new perspective towards an understanding about the relationships at the inter-specific/intra-generic levels. The accessions were divided into eight clusters (Fig. 1), where a single genus for the most part grouped together, but did not form separate clusters, contrary to our expectations.

The Eragrostis accessions were split into three different clusters, which affirmed the fact that Eragrostis is a large and taxonomically complex genus (Tefera et al., 2006). The level of polymorphism among the evaluated Eragrostis accessions was $89.88 \%$, which corresponds with the findings of Bai et al. (2000), who found a high level of polymorphism in wild Eragrostis species by using RAPD analysis. At the same time, they revealed a relatively low polymorphism in the Eragrostis tef accessions. ISSR analysis was also used to uncover the genetic diversity in Eragrostis tef (Assefa et al., 2003). They obtained much lower estimates for genetic similarity among the Eragrostis accessions (0.26 - 0.86). Bai et al. (2000) reported that Eragrostis tef is very close to Eragrostis pilosa, supporting the hypothesis of Ebba (1975) that Eragrostis tef originated from this species. Ayele and Ngyuen (2000) reported that E. pilosa was more closely related to E. tef than E. curvula. Our data are at variance with those findings, because Nei's genetic distance between Eragrostis tef (accession Nos. 53 and 54) and Eragrostispilosa (accession No. 45) were observed at 0.1532 and 0.1725 , respectively. Our findings also showed that E. curvula was more closely related to E. tef.

In order to enhance an understanding of the diversity and relationships in the Pennisetum genus, an ISSR analysis incorporated cultivated, wild, and weed Pennisetum species - P. glaucum, P. purpureum, P. ciliare, and P. sieberianum, respectively. Unfortunately, revealing the relationships among Pennisetum species is rather complicated because Pennisetum is a highly cross-pollinated crop, with large numbers of wild relatives, including those that can be inter-crossed (Jauhar, 1968, 1981; Jauhar and Hanna, 1998). The results of present study may also support this fact, since Pennisetum purpureum was highly differentiated from another Pennisetum accession. The Pennisetum purpureum accession was even present in another/different cluster, and could be detected as an admixed individual, as was similarly revealed by Oumar et al. (2008). Regarding to the genetic relationships of another Pennisetum accession, the clustering showed a close relatedness among the domesticated species $P$. sieberianum and $P$. glaucum. Donadío et al. (2009) obtained similar results; however, they also uncovered a close relatedness of these Pennisetum species to $P$. purpureum, which is in disagreement with the data obtained in current study. In all likelihood, these differences might be attributed to variations in the type and number 
of genotypes, as well as to the techniques employed. Additionally, it should be noted that the grouping of P. glaucum and P. ciliare (syn. Cenchrus ciliaris) accessions strongly supports the finding that Pennisetum and Cenchrus are closely related genera (Clayton and Renvoize, 1986; Crins, 1991). According to Clayton and Renvoize (1986), Cenchrus ciliaris is even considered to be on the boundary between Cenchrus and Pennisetum; and findings of present study support this fact. Although P. ciliare accessions were present in the Pennisetum clusters, they were rather distant from other Pennisetum accessions. Regarding the clustering of all Pennisetum accessions, the clustering reflects both the complicated taxonomy of the Pennisetum genus and of clustering according to geographical origin, which is evident in one of the Pennisetum clusters.

Surprisingly, the Coix lacryma jobi accessions occurred in the Pennisetum cluster, as well (Cluster III). The reason for the clustering of these two Coix accessions with the Pennisetum accessions might have been caused by cross-pollination, which is predominant in Coix sp. (Jansen, 2006). Similarly, the Digitaria exilis accession was present in the same cluster, which supports the view that Pennisetum and Digitaria are considered being a distantly related (Hacker 1995). Additionally, results of the current study demonstrate the complexity of the Digitaria species. These accessions are scattered throughout the entire dendrogram, which reflects considerable variability in the Digitaria genus. Hayward and Hacker (1980) attributed this large specific diversity within the Digitaria genus to its great antiquity, but also to its significant rate of speciation. Findings of present study showed high genetic divergences between the cultivated Digitaria exilis and the other taxonomically distant Digitaria species (Table 1), which is in concordance with the results obtained by Adoukonou-Sagbadja et al. (2010). Among the wild species investigated, D. eriantha and $D$. sanguinalis, there were observed as the most distant, genetically, from the cultivated Digitaria exilis. Nevertheless, it should be noted that different hypotheses exist on the reproductive system of Digitaria species, ranging from inbreeding (Watson and Dallwitz, 1992; Sarker et al., 1993) to out-crossing (Hilu et al., 1997).

Although the Setaria genus is also a complex genus containing crop, wild, and weedy species, with different breeding systems at the life cycle and ploidy levels (Wanous, 1990), all Setaria accessions investigated in the present study grouped together (Fig 1). Thus, our findings do not support the results of the phylogenetic studies performed by Doust et al. (2007) or Kellogg et al. (2009), which indicated that the Setaria genus is a collection of unrelated groups. Although Setaria accessions formed a distinct branch in the present study, no clear geographic structure within the genus was found, contrary to the findings of Li et al. (2012), in which a clear geographic structure was revealed by using ISSR markers. In general, the geographic center from which Setaria originated is still controversial. Single and multiple centers of origin for Setaria have been suggested in Eurasia. A center in northern China was first suggested by Vavilov (1926), and confirmed by many archaeologists and archaeobotanists (Smith, 1998; Lu, 1999; Shelach, 2000); now with some genetic studies having confirmed the existence of this center (Hirano et al., 2011; Li et al., 2012). Nevertheless, the multiple domestication theory is widely accepted (Kawase and Sakamoto 1987; Li et al., 1998; Benabdelmouna et al., 2001; Kawase et al., 2005; Fukunaga et al., 2005, 2006). Despite the limited number of accessions used in the present study, the clustering of the Setaria accessions, and relatively high level of similarity, might suggest a hypothesis of a single center of domestication. Unfortunately, the origin of Setaria still has remained unresolved, and further detailed analysis using large numbers of accessions is required.

The Echinocbloa genus is also a taxonomically complicated genus, because clear-cut boundaries between species seldom exist, and the species are very variable. Introgression between species is also common (Brink and Belay, 2006). Last but not least, its great diversity is also caused by its easy adaptation to a wide range of aquatic and ruderal habitats, combined with self-pollination (Partohardjono and Jansen, 1996). These genetic and morphological differences in the Echinochloa species lead to taxonomic problems. Thus, many studies have attempted to understand the population genetic structures of some Echinochloa species, and have revealed their genetic diversity by using molecular markers (Asins et al., 1999; Roy et al., 2000; Rutledge et al., 2000; Tasrif et al., 2004; Altop and Mennan, 2011; Nozawa et al., 2006; Danquah et al., 2002). As with previous studies, the Echinochloa species in the present study were differentiated, and might confirm the theory of Yabuno (1966) and Scholz (1992), that the weedy Echinochloa crus-galli has its cultivated counterpart Echinocbloa esculenta. Altop and Mennan (2011) mentioned that the variability among Echinochloa accessions from various locations might be due to its adaptability to the geographic locations, as well as differences in weed management practices.

ISSR analysis revealed a high level of polymorphism in the Panicum genus (89.49\%). In the present study, the scattering of Panicum accessions throughout the NJ dendrogram (Fig. 1) and PCoA diagram (Fig. 2) clearly confirmed the fact that the Panicum genus is extremely variable (Hacker, 1995). The most variable Panicum species in the current study is Panicum coloratum, which is a polymorphic species native to tropical Africa. Furthermore, attributes such as predominant cross-pollination or the development of ecotypes adapted to a wide range of soils (Hacker 1995) might be responsible 


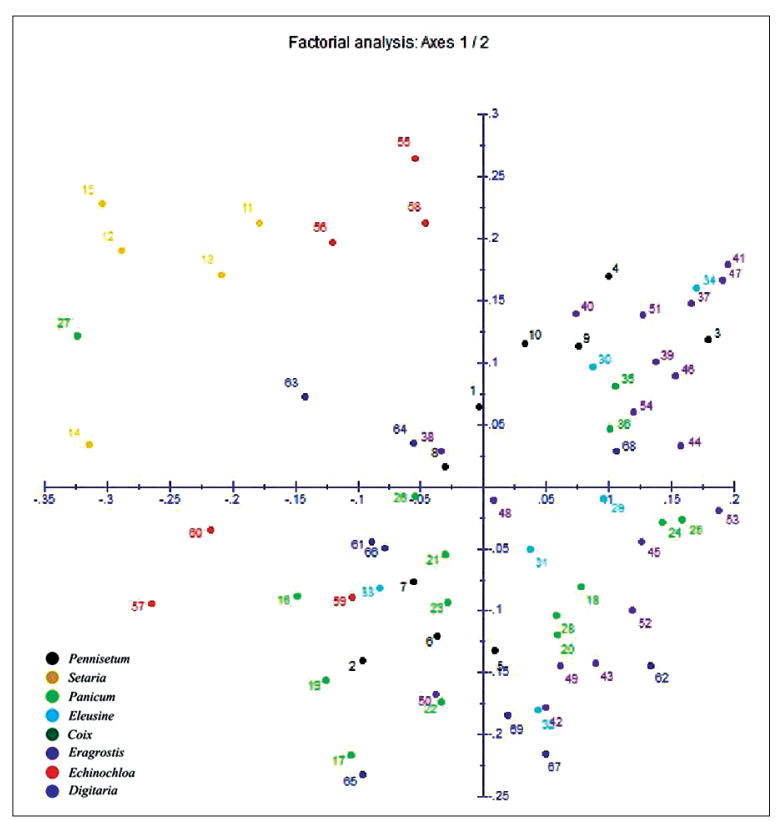

Fig 2. Prinicpal Coordinates Analysis for ISSR data.

for the segregation of $P$. coloratum accessions from other Panicum accessions. Also, the Panicum sumatrense accession was separated from other Panicum accessions, which reflected a high variability (van der Hoek and Jansen, 1996). Further, the clustering of $P$. sumatrense with Setaria accessions is quite in agreement with data obtained by Lakshmi et al. (2002), where P. sumatrense and Setaria italica accessions were present in the same cluster. In addition, Aliscioni et al. (2003) mentioned that the genus shows a wide range of variation, and relationships within the Panicum genus are not completely clear, which was also evident in our study. Also, M'Ribu and Hilu (1994) studied the variation among Panicum species, and their findings revealed the differentiation of individual millet species, which is in accordance with the data obtained in this study. Although most Panicum accessions employed in the present analysis originated in Africa, there were no clear separations of the accessions according to their geographic origins, contrary to the data obtained by Hu et al. (2008) and Hunt et al. (2011).

In contrast to Panicum, the Eleusine genus belongs to a relatively small genus (Phillips, 1972; Hilu and de Wet, 1976), but the classification of the genus has been notoriously difficult, not only at the intra-generic level, where considerable disagreements on species delimitation and their relationships have persisted (Bisht and Mukai, 2001, 2002; Lye, 1999; Phillips, 1972, 1995). This is also true at the supra-generic level, where its closest allies are disputed (Clayton and Renvoize, 1986). Therefore, some studies have used a comparative analysis of DNA markers in order to get greater knowledge of the interrelatedness of the Eleusine species (Gupta et al., 2010; Hiremath and Salimath, 1992; Salimath et al., 1995). Hiremath and Salimath (1992) used molecular markers to uncover the genetic affinities between Eleusine coracana and three diploid species (viz. Eleusine indica, Eleusine floccifolia, and Eleusine tristachya), which are believed to form a close genetic assemblage within the genus. These results are inconsistent with those obtained in the present study. The Eleusine species were clearly separated and scattered throughout the dendrogram, which might indicate an implemented sorting of the Eleusine species. Hence, these findings could be of value towards a better characterization of the genus. Another interesting finding is that the ISSR technique used in the present study revealed a high level of polymorphism (74\%), which is suggestive of the ISSR technique being a most promising tool for uncovering of plant diversity. These findings are in agreement with a comparative study performed by Salimath et al. (1995).

Regarding the level of polymorphism at the genera level, the findings revealed in the present study a broad range of polymorphism. These unique findings confirmed that millets are more or less related. The determination of relatedness might help to resolve the difficult interrelationships among the different millet genera. Despite the fact that Eragrostis and Panicum are complex and variable genera (Tefera and Belay, 2006; Hacker, 1995), the data demonstrated that these genera are the most similar. Further, a close relatedness was also observed between the Eragrostis and Pennisetum genera (Table 3). The genus Pennisetum is also considered to be distantly related to Digitaria (Hacker 1995), which relatively corresponds with our findings. Furthermore, according to our data, the Digitaria genus is close to the Eleusine genus. On the other hand, the Eleusine genus is most distant from the Setaria genus. There has been a hypothesis that Setaria had evolved from Panicum (Brink and Belay, 2006). Nevertheless, the results of this study could not unambiguously confirm this hypothesis due to the relatively high genetic distance. However, the most distant genus from other millet genera implemented in the present study was Coix; with knowledge about this species still being limited.

\section{CONCLUSIONS}

To the best of our knowledge, this is the first report where different millet genera were compared simultaneously using ISSR markers. These markers confirmed the presence of a high level of genetic variability among and within the different millet genera. Further, the ISSR cluster analysis, revealed that the majority of accessions of a given genera tend to group together. On the other hand, it must be noted that in some cases the genus boundaries were not very rigid, and accessions of a given genera were scattered throughout the dendrogram. This clustering is probably due to the variation in the types and number of 
genotypes, species admixtures, different origins of the accessions, different propagation systems, and their ability to adapt to different geographic conditions. Additionally, the results of the present study clearly confirmed the concept that millets are a complex group. Although the present investigation shed some light on a better understanding of the genetic diversity in millets, further studies are required to improve our understanding of the phylogenetic relationships as well as the genetic diversity in millets at the genera/species level.

\section{ACKNOWLEDGEMENT}

This research was supported financially by the Internal Grant Agency of the Czech University of Life Science Prague CIGA (Project No. 20135004) and Internal Grant Agency of the Faculty of Tropical AgriSciences, Czech University of Life Sciences Prague IGA (Project No. 20145020).

\section{Author contributions}

Z. D. performed all the experimental procedures and statistical calculations, carried out drafting and writing the manuscript, and prepared the figures. E. S. helped with experimental procedures and data analysis. P. H. Č. made special data analysis, and helped in drafting the manuscript. D. J., I. V., E. F. C. and L. M. conceived the project, provided guidance in the study design. All authors were involved in revising the manuscript in progress, and critically reading and approving the final manuscript.

\section{REFERENCES}

Adoukonou-Sagbadja, H., C. Wagner, F. Ordon and W. Friedt. 2010. Reproductive system and molecular phylogenetic relationships of fonio millets (Digitaria spp., Poaceae) with some polyploid wild relatives. Trop. Plant Biol. 3: 240-251.

Aliscioni, S. S., L. M. Giussani, F. O. Zuloaga and E. A. Kellogg. 2003. A molecular phylogeny of Panicum (Poaceae: Paniceae): Tests of monophyly and phylogenetic placement within the Panicoideae. Am. J. Bot. 90: 796-821.

Altop, E. K. and H. Mennan. 2011. Genetic and morphologic diversity of Echinochloa crus-galli populations from different origins. Phytoparasitica. 39: 93-102.

Amadou, I., M. E. Gounga and G. W. Le. 2013. Millets: Nutritional composition, some health benefits and processing: A review. Emirates J. Food Agric. 25: 501-508.

Andrews, D. J. and K. A. Kumar. 2006. Pennisetum glaucum (L.) R. Br. In: Brink, M. and G. Belay (Editors). Plant Resources of Tropical Africa 1. Cereals and Pulses. PROTA Foundation, Wageningen, Netherlands, p128-133.

Arya, L., M. Verma, V. K. Gupta and A. Seetharam. 2013. Use of genomic and genic SSR markers for assessing genetic diversity and population structure in Indian and African finger millet (Eleusine coracana (L.) Gaertn.)germplasm. Plant Syst. Evol. 299: 1395-1401.

Asins, M. J., J. L. Carretero, A. Del Busto, E. A. Carbonell and D. De Barreda. 1999. Morphologic and isozyme variation in barnyardgrass (Echinochloa) weed species. Weed Technol. 13: 209-215.

Assefa, K., A. Merker and H. Tefera. 2003. Inter simple sequence repeat (ISSR) analysis of genetic diversity in tef [Eragrostis tef (Zucc.) Trotter]. Hereditas. 139: 174-183.

Ayele, M. and H. T. Nguyen. 2000. Evaluation of amplified fragment length polymorphism markers in tef, Eragrostis tef (Zucc.) Trotter, and related species. Plant Breed. 119: 403-409.

Bahieldin, A., A. M. Ramadan, N. O. Gadalla, A. M. Alzohairy, S. Edris, I. A. Ahmed, A. M. Shokry, S. M. Hassan, O. M. Saleh, M. N. Baeshen, N. A. Radwan, M. A. Al-Kordy, N. Baeshen and F. M. El-Domyati. 2012. Molecular markers for salt tolerant wild barley Hordeum spontaneum. Life Sci. 9: 5838-5847.

Bai, G., M. Ayele, H. Tefera and H. T. Nguyen. 2000. Genetic diversity in tef (Eragrostis tef (Zucc.) Trotter) and its relatives as revealed by random amplified polymorphic DNAs. Euphytica. 112: 15-22.

Baltensperger, D. and Y. Z. Cai. 2004. Minor. In: Wrigley, C., H. Corke and $\mathrm{CH}$. Walker, editors. Encyklopedia of Grain Science. Academic Press, Elsevier, p261-268.

Belton, P. S. and J. R. N. Taylor. 2003. Sorghum and millets: Protein sources for Africa. Trends Food Sci Tech 15(2): 94-98.

Benabdelmouna, A., M. Abirached-Darmency and H. Darmency. 2001. Phylogenetic and genomic relationships in Setaria italica and its close relatives based on the molecular diversity and chromosomal organization of $5 S$ and 18S-5.8S-25S rDNA genes. Theor. Appl. Genet. 103: 668-677.

Ben El Maati, F., M. Jlibene and M. Moumni. 2004. Study of the polymorphism of common wheat using ISSR markers. J. Food Agric. Environ. 2: 121-125.

Bisht, M. S. and Y. Mukai. 2001. Genomic in situ hybridisation identifies genome donor of finger millet (Eleusine coracana). Theor. Appl. Genet. 102: 825-832.

Bisht, M. S. and Y. Mukai. 2002. Genome organization and polyploid evolution in the genus Eleusine (Poaceae). Plant Syst. Evol. 233: 243-258.

Brink, M. and G. Belay. 2006. Plant Resources of Tropical Africa 1. Cereals and Pulses. PROTA Foundation, Wageningen, Netherlands/Backhuys Publishers, Leiden, Netherlands/CTA, Wageningen, Netherlands, p298.

Clayton, W. D. and S. A. Renvoize. 1986. Genera Graminum: Grasses of the World. Kew Bulletin, Additional Series 13.HMSO, London.

Crins, W. J. 1991. The genera of Paniceae (Gramineae: Panicoideae) in the Southeastern United States. J. Arnold. Arbor. 1: 205-220.

Danquah, E. Y., D. E. Johnson, C. Riches, G. M. Arnold and A. Karp. 2002. Genetic diversity in Echinochloa spp. collected from different geographic origins and within rice fields in Cote d'Ivoire. Weed. Res. 42: 394-405.

Desai, B. B. 2004. Seeds Handbook: Biology, Production, Processing, and Storage. Marcel Dekker, New York.

Dice, L. R. 1945. Measures of amount of ecological association between species. Ecology. 26: 297-302.

Donadío, S., L. M. Giussani, E. A. Kellogg, F. O. Zuolaga and O. Morrone. 2009. A preliminary molecular phylogeny of Pennisetum and Cenchrus (Poaceae-Paniceae) based on the trn L-F, rpl16 chloroplast markers. Taxon. 58: 392-404.

Doust, A. N., A. M. Penly, S. W. L. Jacobs and E. A. Kellogg. 2007. Congruence, conflict and polyploidization shown by nuclear and chloroplast markers in the monophyletic "bristle clade" (Paniceae, Panicoideae, Poaceae). Syst. Bot. 32: 531-544.

Ebba, T. 1975. Tef (Eragrostis tef) cultivars. Morphology and classification. Part II. Agricultural Experiment Station Bulletin No. 66. Addis Ababa University, College of Agriculture, Dire Dawa, Ethiopia. 
FAO. 1995. Sorghum and Millets in Human Nutrition. FAO Food and Nutrition Series, No. 27, Rome.

Fukunaga, K., K. Ichitani and M. Kawase. 2006. Phylogenetic analysis of the rDNA intergenic spacer subrepeats and its implication for the domestication history of foxtail millet, Setaria italica. Theor. Appl. Genet. 113: 261-269.

Fukunaga, K., K. Ichitani, S. Taura, M. Sato and M. Kawase. 2005. Ribosomal DNA intergenic spacer sequence in foxtail millet, Setaria italica (L.) P. Beauv. and its characterization and application to typing of foxtail millet landraces. Hereditas. 142: 38-44.

Garí, J. A. 2002. Review of the African millet diversity. Paper for the International workshop on fonio, food security and livelihood among the rural poor in West Africa. Edited by the Programme for Neglected and Underutilised Species International Plant Genetic Resources Institute, Rome, Italy. Available from: http:// www.fao.org/sd/LINKS/documents_download/millets.pdf. [Last accessed on 2014 Apr 16].

Gupta, R, K. Verma, D. C. Joshi, D. Yadav and M. Singh. 2010. Assessment of genetic relatedness among three varieties of finger millet with variable seed coat colour using RAPD and ISSR markers. Genet. Eng. Biotechnol. 2010: GEBJ-2.

Hacker, J. B. 1995. Tropical and subtropical grasses. In: Smartt, J. and N. W. Simmonds editors. Evolution of Crop Plants. $2^{\text {nd }}$ ed. Longman Group UK Limited, Harlow, p229-237.

Hayward, M. D. and J. B. Hacker. 1980. Genetic control of some esterase isozymes of Digitaria species, and their utility in the identification of hybrids. Euphytica. 29: 347-356.

Hilu, K. W. and J. M. J. de Wet. 1976. Domestication of Eleusine coracana (L.). Econ. Bot. 30: 199-208.

Hilu, K. W., K. M'Ribu, H. Liang and C. Mandelbaum. 1997. Fonio millets: Ethnobotany, genetic diversity and evolution. S. Afr. J. Bot. 63: 185-190.

Hirano, R., K. Naito, K. Fukunaga, K. N. Watanabe, R. Ohsawa and M. M. Kawase. 2011. Genetic structure of landraces in foxtail millet (Setaria italica (L.) P. Beauv.) revealed with transposon display and interpretation to crop evolution of foxtail millet. Genome. 54: 498-506.

Hiremath, S. C. and S. S. Salimath. 1992. A genome donor of Eleusine coracana (Gramineae). Theor. Appl. Genet. 84: 747-754.

Hu, Y. G., J. Zhu, F. Liu, Z. Zhang, Y. Chai and S. Weining. 2008. Genetic diversity among Chinese landraces and cultivars of broomcorn millet (Panicum miliaceum) revealed by the polymerase chain reaction. Ann. Appl. Biol. 153: 357-364.

Hu, X., J. Wang, P. Lu and H. Zhang. 2009. Assessment of genetic diversity in broomcorn millet (Panicum miliaceum L.) using SSR markers. J. Genet. Genomics. 36: 491-500.

Hunt, H. V., M. G. Campana, M. C. Lawes, Y. J. Park, M. A. Bower, C. J. Howe and M. K. Jones. 2011. Genetic diversity and phylogeography of broomcorn millet (Panicum miliaceum L.) across Eurasia. Mol. Ecol. 20: 4756-4771.

Hutchenson, K. 1970. A test for comparing diversities based on the Shannon formula. J. Theor. Biol. 29: 151-154.

Jansen, P. C. M. 2006. Coix lacryma-jobi L. In: Brink, M. and G. Belay, editors. Plant Resources of South-East Asia No 10. Cereals. Backhuys Publishers, Leiden, Netherlands, p90-95.

Jansen, P. C. M. and H. C. Ong. 1996. Eleusine coracana (L.) gaertner cv. Group finger millet. In: Grubben, and S. Partohardjono, editors. Plant Resources of South-East Asia No 10. Cereals. Backhuys Publishers, Leiden, Netherlands, p90-95.

Jauhar, P. P. 1968. Inter-and intra-genomal chromosome pairing in an inter-specific hybrid and its bearing on the basic chromosome number in Pennisetum. Genetica. 39: 360-370.
Jauhar, P. P. 1981. Cytogenetics of pearl millet. Adv. Agron. 34: 407479.

Jauhar, P. P. and W. W. Hanna. 1998. Cytogenetics and genetics of pearl millet. In: Sparks, D. L ,editor. Advances in Agronomy. Academic Press, USA,

Kalinová, J. and J. Moudrý. 2006. Content and quality of protein in proso millet (Panicum miliaceum L.) varieties. Plant Food Hum. Nutr. 61: 45-49.

Kaume, R. N. 2006. Panicum miliaceum L. In: Brink M, Belay G, editors. Plant Resources of Tropical Africa 1. Cereals and Pulses. PROTA Foundation, Wageningen, Netherlands , p122-126.

Kawase, M., K. Fukunaga and K. Kato. 2005. Diverse origins of waxy foxtail millet crops in East and Southeast Asia mediated by multiple transposable element insertions. Mol. Genet. Genomics. 274: 131-140.

Kawase, M. and S. Sakamoto. 1987. Geographical-distribution of landrace groups classified by hybrid pollen sterility in foxtail millet, Setaria Italica (L) Beauv, P. Jpn. J. Breed. 37: 1-9.

Kellogg, E. A., S. S. Aliscioni, O. Morrone, J. Pensiero and F. Zuloaga. 2009. A phylogeny of Setaria (Poaceae, Panicoideae, Paniceae) and related genera, based on the chloroplast gene ndh F. Int. J. Plant Sci. 170: 117-13.

Kim, S., C. S. Kim, J. Lee, I. Y. Lee, Y. J. Chung, M. S. Cho and S. CH. Kim. 2014. Phylogenetic relationships among species of Setaria (Paniceae; Panicoideae; Poaceae) in Korea: Insights from nuclear (ITS and kn1) and chloroplast DNA sequence data. Plant Syst. Evol. 301: 725-736.

Lakshmi, M., M. Parani, S. Rajalakshmi and A. Parida. 2002. Analysis of species relationship among seven small millets using molecular markers. J. Plant Biochem. Biotechnol. 11: 85-91.

Lasztity, R. 1996. Millet proteins. In: Lasztity, R, editor. The Chemistry of Cereal Proteins. CRC Press, USA, p295-308.

Le Thierry d'Ennequin, M., O. Panaud, B. Toupance and A. Sarr. 2000. Assessment of genetic relationships between Setaria italica and its wild relative S. viridis using AFLP markers. Theor. Appl. Genet. 100: 1061-1066.

Li, Y., J. Z. Jia, Y. Wang and S. Z. Wu. 1998. Intraspecific and interspecific variation in Setaria revealed by RAPD analysis. Genet. Resour. Crop. Evol. 45: 279-285.

Li, J. M. and Z. X. Jin. 2008. Genetic structure of endangered Emmenopterys henryi Oliv. based on ISSR polymorphism and implications for its conservation. Genetica. 133: 227-234.

Li, H., C. J. Ruan and J. A. Teixeira da Silva. 2009. Identification and genetic relationship based on ISSR analysis in a germplasm collection of sea buckthorn (Hippophae L.) from China and other countries. Sci. Hortic. Amst. 123: 263-271.

Li, W., H. Zhi, Y. F. Wang, H. Q. Li and X. M. Diao. 2012. Assessment of genetic relationship of foxtail millet with its wild ancestor and close relatives by ISSR markers. J. Integr. Agric. 11: 556-566.

Lin, H. S., G. Liao, C. Y. Chiang, S. B. Chang, G. I. Liao and C. S. Kuoh. 2012. Genetic diversity in the foxtail millet (Setaria italica) germplasm as determined by agronomic traits and microsatellite markers. Aust. J. Crop. Sci. 6: 342-349.

Lu, T. L. D. 1999. The Transition from Foraging to Farming and the Origin of Agriculture in China. BAR International Series 774 Hadrian, Oxford, UK, p233.

Lye, K. A. 1999. Nomenclature of finger millet (Poaceae). Lidia. 4: $149-151$

McKevith, B. 2004. Nutritional aspects of cereals. Nutr. Bull. 29: 257-268.

Mondini, L., H. Grausgruber and M. A. Pagnotta. 2014. Evaluation of European emmer wheat germplasm for agro-morphological, 
grain quality traits and molecular traits. Genet. Resour. Crop. Evol. 61: 69-87.

M'Ribu, H. K. and K. W. Hilu. 1994. Detection of interspecific and intraspecific variation in Panicum millets through random amplified polymorphic DNA. Theor. Appl. Genet. 88: 412-416.

Nei, M. 1972. Genetic distance between populations. Am. Nat. 106: 283-292.

Nei, M. and N. Takezaki. 1983. Estimation of genetic distances and phylogenetic trees from DNA anlysis. Proc. $5^{\text {th }}$ World Cong. Genet. Appl. Livstock. Prod. 21: 405-412.

Nozawa, S., M. Takahashi, H. Nakai and Y. I. Sato. 2006. Difference in SSR variations between Japanese barnyard millet (Echinochloa esculenta) and its wild relative E. crus-galli. Breed. Sci. 56: 335-340.

National Research Council. 1996. Lost crops of Africa. Vol. 1. Grains, National Academy Press, Washington, DC.

Obilana, A. B. and E Manyasa. 2002. Millets. In: Belton, P. S. and J. R. N. Taylor, editors. Pseudocereals and Less Common Cereals: Grain Properties and Utilization Potential. Springer, Berlin, p177-218.

Oumar, I., C. Mariac, J. L. Pham and Y. Vigouroux. 2008. Phylogeny and origin of pearl millet (Pennisetum glaucum [L.] R. Br) as revealed by microsatellite loci. Theor. Appl. Genet. 117: 489-497.

Partohardjono, S. and P. C. M. Jansen. 1996. Echinochloa P. Beauvois. In: Grubben, G. J. H and S. Partohardjono, editors. Plant Resources of South-East Asia No 10. Cereals. Backhuya Publishers, Leiden, Netherlands, p87-90.

Pedraza-Garcia, F., J. E. Specht and I. Dweikat. 2010. A new PCRbased linkage map in pearl millet. Crop. Sci. 50: 1754-1760.

Perrier, X. and Jacquemoud-Collet, J. P. 2006. DAR win Software. Available from: http://www.darwin.cirad.fr/darwin. [Last accessed on 2013 Oct 18].

Phillips, S. M. 1972. A survey of the genus Eleusine in Africa. Kew Bull. 27: 251-270.

Phillips, S. M. 1995. Poaceae (Gramineae). In: Hedberg, I. and S. Edwards, editors. Flora of Ethiopia and Eritrea. Vol. 7. The National Herbarium, Addis Ababa University, Addis Ababa, and Department of Systematic Botany, Uppsala University, Uppsala, p1-420.

Qin, F., J. Li, X. Li and H. Corke. 2005. AFLP and RFLP linkage map in Coix. Genet. Resour. Crop. Evol. 52: 209-214.

Ramezani, H. 2012. A note on the normalized definition of shannon's diversity index in landscape pattern analysis. Environ. Nat. Resour. Res. 2: 54-60.

Roy, S., J. P. Simon and F. J. Lapointe. 2000. Determination of the origin of the cold-adapted populations of barnyardgrass (Echinochloa crus-galli) in eastern North America: A total evidence approach using RAPD DNA and DNA sequences. Can. J. Bot. 78: 1505-1513.

Rutledge, J., R. E. Talbert and C. H. Sneller. 2000. RAPD analysis of genetic variation among propanil-resistant and susceptible Echinochloa crus-galli populations in Arkansas. Weed. Sci. 48: 669-674.

Saitou, N. and M. Nei. 1987. The neighbor-joining method: A new method for reconstructing phylogenetic trees. Mol. Biol. Evol. 4: 406-425.

Salimath, S. S., A. C. De Oliveira, I. D. Godwin and J. L. Bennetzen. 1995. Assessment of genome origins and genetic diversity in the genus Eleusine with DNA markers. Genome. 38: 757-763.

Sarker, S., D. V. S. Tyagi and M. H. Islam. 1993. Induced mutagenesis:
An important tool for breeding small millets: A review. Agric. Rev. Karnal. 14: 61-65.

Schlüter, P. M. and S. A. Harris. 2006. Analysis of multilocus finger printing data sets containing missing data. Mol. Ecol. Notes. 6: $569-572$.

Scholz, H. 1992. Echinochloa esculenta, comb. nov. The correct name of Japanese barnyard millet (Gramineae). Taxon. 41: 522523.

Sheeja, G., S. Jyotsna and L. Y. Vern. 2009. Genetic diversity of the endangered and narrow endemic Piperia yadonii (Orchidaceae) assessed with ISSR polymorphisms. Am. J. Bot. 96: 2022-2030.

Shelach, G. 2000. The earliest Neolithic cultures of Northeast China: Recent discoveries and new perspectives on beginning of agriculture. J. World. Prehist. 14: 363-41.

Smith, B. D. 1998. The Emergence of Agriculture. Scientific American Library, New York.

Supriya, A., S. Senthilvel, T. Nepolean, K. Eshwar, V. Rajaram, R. Shaw, C. T. Hash, A. Kilian, R. C. Yadav and M. L. Narasu. 2011. Development of a molecular linkage map of pearl millet integrating DArT and SSR markers. Theor. Appl. Genet. 123: $239-250$

Tasrif, A., A. S. Juraimi, J. Kadir, S. S. Sastroutomo and S. Napis. 2004. Genetic diversity of Echinochloa crusgalli var. crus-galli (L.) Beauv. (Barnyardgrass: Poaceae) ecotypes in Malaysia and Indonesia as revealed by RAPD markers. Asian. J. Plant Sci. 3: $231-238$.

Taylor, J. R. N., T. J. Schober and S. R. Bean. 2006. Novel food and non-food uses for sorghum and millets. J. Cereal. Sci. 44: 252-271.

Tefera, H. and G. Belay. 2006. Eragrostis tef (Zuccagni) Trotter. In: Brink, M. and G. Belay, editors. Plant Resources of Tropical Africa 1. Cereals and Pulses. PROTA Foundation, Wageningen, Netherlands/Backhuys Publishers, Leiden, Netherlands/CTA, p68-72.

Van der Hoek, H. N. and P. C. M. Jansen. 1996. Minor cereals. In: Grubben, G. J. H. and S. Partohardjono, editors. Plant Resources of South-East Asia No. 10. Cereals. Backhuya Publishers, Leiden, the Netherlands, p150-156.

Vavilov, N. I. 1926. Studies on the origin of cultivated plants. Inst. Appl. Bot. Plant Breed. 16: 1-248.

Virk, P. S., J. Zhu, H. J. Newbury, G. J. Bryan, M. T. Jackson and B. V. Ford-Lloyd. 2000. Effectiveness of different classes of molecular markers for classifying and revealing variation in rice (Oryza sativa) germplasm. Euphytica. 112: 275-284.

Wanous, M. K. 1990. Origin, taxonomy and ploidy level of foxtail millet and minor cereals. Plant Var. Seeds. 3: 99-112.

Watson, L. and M. J. Dallwitz. 1992. The grass genera of the world: Descriptions, illustrations, identification, and information retrieval; including synonyms, morphology, anatomy, physiology, phytochemistry, cytology, classification, pathogens, world and local distribution, and reference. Available from: http://www. delta-intkey.com. [Last accessed on 2014 Apr 21].

Winch, T. 2006. Growing Food: A Guide to Food Production. $1^{\text {st }}$ ed. Springer, Netherlands, p333.

Wolfe, A. D. and A. Liston. 1998. Contributions of PCR-based methods to plant systematics and evolutionary biology. In: Soltis, D. E., P. S. Soltis and J. J. Doyle, editors. Plant Molecular Systematics II. Kluwer Academic Publishers, Dordrecht, Netherlands.

Yabuno, T. 1966. Biosystematic study of the genus Echinochloa. Jpn. J. Bot. 19: 277-323.

Yang, W., A. C. de Oliveira, I. Godwin, K. Schertz and J. L. Bennetzen. 1996. Comparison of DNA marker technologies in characterizing 
plant genome diversity: Variability in Chinese sorghums. Crop. Sci. 36: 1669-1676.

Yu, J. K., R. V. Kantety, E. Graznak, D. Benscher, H. Tefera and M. E. Sorrells. 2006. A genetic linkage map for tef [Eragrostis tef (Zucc.) Trotter]. Theor. Appl. Genet. 113: 1093-1102.

Zamani, P., M. Akhondi, M. R. Mohammadabadi, A. A. Saki, A. Ershadi, M. H. Banabazi and A. R. Abdolmohammadi. 2011. Genetic variation of Mehraban sheep using two inter-simple sequence repeat (ISSR) markers. Afr. J. Biotechnol. 10: 1812-1817.

Zeid, M., K. Assefa, A. Haddis, S. Chanyalew and M. E. Sorrells. 2012. Genetic diversity in tef (Eragrostis tef) germplasm using SSR markers. Field Crop. Res. 127: 64-70.

Zietkiewicz, E., A. Rafalski and D. Labuda. 1994. Genome fingerprinting by simple sequence repeat (SSR) - anchored polymerase chain reaction amplification. Genomics. 20: 176-183. 